\title{
USF FEDERAL CREDIT UNION ${ }^{1}$
}

Rick Skaggs took a deep breath and stared intently out the window of his corner office located on the campus of the University of South Florida. He had heard that renowned professors at MIT were paid to stare out their window and think about hard problems. He was thinking about hard problems and he was staring out the window, but he was not a professor at MIT. Rick Skaggs had been the President and CEO of the USF Federal Credit Union for the last two years. The Chairman of the Board of Directors often "joked" about Mr. Skaggs as still being on probation. Sometimes it felt like that.

Rick Skaggs was hired to take the USF Federal Credit Union to new and improved levels of service across all facets of the organization. Looking back over the last two years, much had been accomplished, and yet so much remained to be done. Maybe it seemed that way because some of the advances required fundamental changes. These grounded changes were not just in technology but also included fundamental cultural changes that would be needed to accommodate the growing credit union. Rick Skaggs also knew that many changes remained before "visible" progress would be noticed. Hopefully the board of directors would also understand the fundamental challenges presented by the changing environment. Furthermore, it had become clear that the entire IT infrastructure needed an overhaul before any of the more progressive initiations could be undertaken.

Although he sometimes felt surrounded by seemingly "insurmountable opportunities", these reflected the very reason that Skaggs had joined the USF Federal Credit Union - to make a difference. The challenge was balancing those needs with the time (and resources) needed to address those needs. The board of directors has been supportive in the direction and vision of the credit union he had articulated, he was also attentive to the desire of the board to make the advances as soon as reasonably possible. No pressure right...

At the present moment, he was reflecting on setting specific priorities. Now that concerns relating to the credit union's IT infrastructure had been addressed, the opportunities to employ technology to expand in a variety of ways had multiplied. Over a dozen worthy projects has been identified. Some of these related to better serving existing customers, some involved services that might help to retain customers (many of whom changed financial partners after they graduated), some could help attract new customers, and some would increase the efficiency of internal operations. Since the USF-FCU did not have the financial or personnel resources to pursue all of these at once, the question was where to start? And, having made up his own mind, how to justify his recommendation to the Board of Directors?

\footnotetext{
${ }^{1}$ Copyright (C) 2013, Informing Science Institute. Edited by Grandon Gill. This case was prepared for the purpose of class discussion, and not to illustrate the effective or ineffective handling of an administrative situation. Permission is granted to copy and distribute this case for non-commercial purposes, in both printed and electronic formats. This material is based upon work supported by the National Science Foundation under Grant No. 1043919.
} 


\section{Credit Unions}

Sixty percent of you don't know what a credit union does. Hmmm... what if sixty percent of people didn't know what coffee is, or what a car wash is, or what pants are. A credit union is a better place to do your banking, checking, savings, loans, everything. And being not-for-profit, their rates and fees are usually lower

It's kinda like... finding money... everyday.

Credit unions in Florida saved their members \$239,740,248 last year.

CREDIT UNIONS we're giving banking a better name.

CREDIT UNIONS BetterNameForBanking.com

- $\quad$ Credit Union Commercial $2012 \quad$-.

The credit union movement originated with the idea that members of a community could increase their standard of living by pooling their financial resources and making loans to their neighbors and coworkers. Credit unions are basically community-based banks that operate as a cooperative. Functioning as a cooperative, credit unions are member owned and are operated for the benefit of its members.

The first credit unions originated in Germany about 1849 to find alternatives to various loan sharks of the day. The credit union cooperatives were founded to assist the working class in their efforts to gain better financial services. It was estimated that by 1913, 2 million Germans were members of credit unions, most of which were in rural areas with communities of less than 3000 people (Guinnane, 2001). The movement defied opponents who argued that poor Germans would not repay their loans.

The first Credit Union in the United States was established in 1909 in Manchester, New Hampshire. In 1921, the Credit Union National Extension Bureau was organized to enact credit union laws and form credit unions. President Franklin D. Roosevelt signed the Federal Credit Union Act into law in 1921 to enable federally chartered credit unions in all states. It was not until 1970 that the National Credit Union Administration (NCUA) was formed to charter, supervise and insure credit union deposits through the National Credit Union Share Insurance Fund (NCUSIF). The NCUSIF is administered by the NCUA and is entirely funded by participating credit unions.

Being member-owned and not required to generate profits for shareholders, many banks complained that credit unions had an unfair competitive advantage. In 1996, The District of Columbia Federal Appeals Court issued an injunction prohibiting federal credit unions from extending their membership beyond the original core membership group. During President Clinton's administration, the Credit Union Membership Access Act was signed into law in 1998. This act further defined the fiscal responsibilities of federal credit unions and the definition of membership formation.

Serving a clearly defined group of members - who were both customers and owners - credit unions were able to provide a portfolio of services tightly focused on member needs. These included asset-based loans (e.g., car loans and mortgages), credit cards, interest-bearing savings and money-market accounts and nofee or low-fee checking accounts. Because most credit unions were local, they tended to provide hightouch service out of local offices, rather than moving rapidly to Internet-based banking. They were, however, generally able to achieve a national presence through reciprocal relationships with other local credit unions. 


\section{USF Federal Credit Union}

USF Federal Credit Union was chartered in 1959 to serve the financial needs of the staff and faculty at the University of South Florida. It became a Federal Credit Union, regulated and insured by the National Credit Union Administration (NCUA) in 1985. The field of membership expanded to include students in 1990. The Credit Union was located in various University-provided locations until 1972, when the State of Florida leased land to USF Federal Credit Union to build a permanent facility of approximately 3,000 square feet. The main office enlarged in 1981, 1985, and 1997, bringing the total office space to 24,000 square feet. By 2012 USF Federal Credit Union had over 33,000 members with assets of over $\$ 415,000,000$.

The mission statement of the USF-FCU is presented in Exhibit 1.

USF Federal Credit Union had performed relatively well during the challenging national and global financial crisis from 2008-2012. Key financial indicator trends and growth trends were important to assess the long-term performance of financial institutions, including credit unions. Some key indicators, shown in Exhibit 2, included comparisons of USF-FCU with their peer group and with the national average. The peer group consisted of those credit unions with approximately the same asset level. Specifically:

- Net Worth Ratio. This indicated the stability of the credit union. Typically, larger was better. National averages were around 10 percent. If assets grew and Capital did not grow proportionally, then this ratio would decline.

- Return on Average Assets (ROAA). The ROAA measured net worth in relation to average assets, representing the bottom line. A positive ratio would indicate that earnings covered operating expenses and cost of funds. ROAA was calculated as Net Income (loss) [with the option of excluding Temporary Corporate Credit Union Stabilization Income/Expense and NCUSIF Premium Expense] divided by average assets. The presence of a Stabilization Expense in the Exhbit 2 ROAA graph should be readily apparent.

- Operating Expenses as Percentage of Average Assets. OEPAA was an indicator of cost control. Obviously, the lower the percentage, the more efficiently the company appeared to be performing.

- Annualized Rate of Growth. An indicator of how quickly credit union assets were growing. The "annualization" refers to the fact that the growth rate is averaged over the course of a year.

- Provision for Loan Losses (as a percentage of Average Assets). Refers to the expense that is set aside for potential losses on loans. The credit union reserved funds to cover estimated future losses, with higher percentages indicating that the perceived risk of the loan portfolio was higher.

- Quarterly Membership Growth (Annualized). Benchmarks the percentage change in membership growth from period to period against peer and national averages.

\section{Management}

As a member-serving organization, the management and governance structure of the USF-FCU was complex, meeting the needs of various stakeholders. The three principal bodies were as follows:

- Senior Management Team, consisting of employees charged with running the operations of the organization. The team is presented in Exhibit 3. In the two years leading up to early 2012, the 


\section{WILL \& SKAGGS}

senior management team at USF-FCU had experienced significant changes. Among the key officers, Rick Skaggs, President/CEO joined the credit union in September, 2010. The Chief Information Officer - CIO, Peggy Yenny (a USF College of Business, Information Systems graduate), joined the team in June, 2011. Most recently, Miles Strickland, Chief Financial Officer - CFO, had joined the credit union in October, 2011, replacing the retiring CFO of several years. The Senior Vice President, Bruce Koehler, and the Assistant Vice President of HR, Shelli Nicola, had been with the credit union for several years. The latest addition to the senior management team was John LoCascio, Assistant Vice President of Retail Operations. John was hired to focus on process improvements, to fine tune products to meet member needs, further develop sales and service operations, and to capitalize on business development opportunities to provide exceptional service to credit union members while maximizing growth prospects.

- Board of Directors, consisting of volunteers - mainly USF faculty members (about half of whom were from the College of Business), who worked with the management team to establish the organization's strategic direction. The range of tenure for these volunteers was from 1996-2011. The board is presented in Exhibit 4.

- Supervisory Committee, also consisting of volunteers, charged with oversight. It met on various occasions during the year to help establish and oversee auditing practices at the credit union. The committee's members are presented in Exhibit 5.

All of the senior management team, board of directors, and supervisory committee meet annually for a strategic planning session.

Newly created positions included the CIO mentioned above, a new Internal Audit Manager (2012), and a new Assistant Vice President of Retail Services (2012). The Retail Services position was a consolidation of functions previously assigned to multiple employees. All of the newly created positions were approved by the board of directors.

\section{Operations and Services}

The USF Federal Credit Union, like other financial institutions, generated income to maintain and/or enhance operations and services to its members. Bruce Koehler, Senior Vice President, made the mission clear:

Since a credit union is member owned, profit is not the primary motivation - covering operating expenses and providing valuable services to its members is the primary mission.

Koehler further emphasized that the credit union was an "anti-fee" establishment. As with any financial institution, however, there would be some behavior-drive fees - such as late-payment and over-draft. Those fees are used to adjust behavior in that they tend to motivate members to make timely payments.

As would be the case for nearly any banking institution, USF-FCU operating income was most commonly generated is through loans. The types of loans offered were as follows:

- Automobile, available throughout the us, through the network of credit unions with reciprocal relationships

- Home, available only in Florida

- Business

- Consumer

- Student

- Credit card 
The rates of the above loans varied depending on economic conditions such as the prime lending rate and on the credit score of the member(s) applying for the loan. These were the primary sources of funding for the credit union.

Some operating income funds were also generated from investments. By law, credit unions could only invest their funds in highly secure instruments, such as U.S. treasury bills. As a consequence of the lowinterest policies instituted by the U.S. Federal Reserve Bank over the previous decade, however, these were generating very little revenue at the time of the case.

Credit cards were, in some respects, the most complex source of income. The bank or credit union sponsoring the card provided the working capital necessary to pay merchants for purchases made with the card. In return, they received revenue primarily from three sources:

- Interchange Fees: The income generated from the swiping the card, with the bank's share amounting to under $1 \%$ of the purchase. These fees were collected from international credit card companies, most notably Master Card and VISA, who charged merchants a larger percentage that could vary depending on the type of transaction (gas, grocery store, restaurants, etc.)

- Interest Income: The income that came from members carrying a balance. The annual percentage rate (APR) of this interest was determined by the bank or credit union, and was normally tiered according to the card holder's credit worthiness and payment history.

- Fees: Revenue from late fees, transfer balance fees and over-limit fees. Some banks also charged an annual fee to card holders, but this was generally inconsistent with the no/low fee policies that guided credit unions.

\section{Information Technology at USF-FCU}

The USF Federal Credit Union was seeking to become a "fast follower" in its utilization of information technology. According to the Skaggs, this meant being efficient and effective in using proven technology both internally and externally (for members). Candidly, he noted that it had not always been that way.

\section{Evolution of IT at USF-FCU}

Since the 1990s, the USF-FCU had been operating with a Symitar software solution delivered on in-house IBM based hardware. Symitar was one of the largest core processing systems in the credit union industry. The USF-FCU had depended on Symitar for all of its data processing needs. Its IBM mainframe hardware had last been replaced in 2001.

In 2010, at a strategic planning session, one of the then supervisory committee members summarized the technology at USF-FCU as "kludgy". The word caught on as something that needed to be addressed in the services that could be - and needed to be-offered at the credit union. A USF-FCU volunteer made the following statement at the 2010 Strategic Planning Session:

Although the various systems at USF-FCU are functional, they are neither easy to use nor integrated. A member continually has to sign into different systems to conduct business. It seems that we are actually doing business on a variety of sites with different user interfaces.

As the newly appointed CEO/President, Skaggs indicated that if the board wanted him to improve information technology at USF-FCU, he would need to hire someone to assist with implementing new tech- 


\section{WILL \& SKAGGS}

nology. The volunteer recommended that a CIO (as opposed to an IT Manager) be hired to help establish and oversee the strategic direction and implementation of those needed IT dependent services.

Other issues raised at both the 2010 and 2011 strategic planning sessions included the need to identify and implement "sticky" products. Sticky products and/or services were perceived to have a variety of characteristics. Possibly the most important is that once a customer started using a "sticky" product/service, he or she was less likely to want to switch to another product/service because it was just too convenient to "stay put". These services were typically simple to use, and extremely handy. The consensus at the meeting was that services at the credit union that could be considered "sticky" would be on-line bill pay and on-line deposits. From a technology component standpoint, this meant the ability to perform many of the members' needed financial services on-line.

One final issue raised at the two most recent strategic planning sessions included building an understanding of what products/services were needed to keep members at the USF-FCU. USF students often joined the USF federal credit union; for many, it was their first financial institution partnership. Those that did join, however, would eventually graduate and then begin their careers-frequently outside the TampaBay area. When members left the area, they also tended to leave the USF-FCU. What if there were sufficient and adequate technology such that a member would not need to change financial institutions? What would it take to keep students as members long after they had become alumni of the University of South Florida? These questions were raised by the volunteers at the strategic planning sessions. Finding answers could help USF build an even stronger and more helpful credit union.

In June of 2011, USF-FCU's first CIO, Peggy Yenny, was brought on-board. Very quickly, she identified the existing hardware/software environment as challenging. She noted that these core processing mainframes were normally replaced every five years. The conclusion was inescapable. The USF-FCU was running on "vulnerable" equipment that was at capacity and offered no opportunity to add any products or services to the current mix.

Recognizing this, one of her first actions was to provide adequate upgrades to the existing systems in order to stabilize the operating system environment. Disk storage was added along with additional memory for Symitar. The AIX mainframe core operating system was upgraded to a more current version and backup storage was increased.

To move towards a more permanent solution, Yenny presented a lease-purchase analysis to the board of directors, including a graphic comparison of the current in-house environment with the proposed outsourced solution (Exhibit 6). The analysis recommended moving to an "...EASE (Episys as a Service) on-line solution offered by Symitar". The outsourced solution was consistent with the current operations and offered the possibility of adding products and services, utilizing existing personnel "...to concentrate on business objectives and strategic initiatives". She also explained that this solution would allow the USF-FCU “...to focus on core competencies with seamless access to advancing technology, strict regulatory compliance, and ongoing access to industry, technology, and security experts". The new platform would enable the introduction of new products and services.

The Board of Directors had been expecting, even anticipating, the need for such improvements in technology. According to director's comments, this was a welcome opportunity and new direction for the credit union. Following due-diligence discussion at the June, 2011 board of directors meeting, the proposal passed unanimously. 


\section{Current Initiatives}

Skaggs presented a Critical Success Factors Update to the board of directors at the January 2012 board meeting. The technology component was summarized below.

The migration to Symitar's EASE (Episys as a Service) over the October 28th 2011 weekend was a huge step towards improving the integration of our systems. Without this migration we would be years behind in rolling our new technology to our members. We are concentrating our resources on our processes and how we can interface with other systems more seamlessly.

An EPIC (Episys Process Improvements Committee) was created. Individuals across the credit union are assigned to each EPIC to assist in the rollout of new products, services, and applications.

We continue to focus our resources and capital expenditures on stabilizing the Information Technology infrastructure. This focus will continue through 2012.

Information technology was also implemented to increase user employee's involvement and contribution to the mission and operation of the credit union. The update continued:

An intranet solution was rolled out that gives every department an avenue to communicate the activities and challenges in each area. This also provides one are for credit union documentation to reside.

Our Help Desk and Project Management Solution has provided users a process to report an issue and track the progress of solving the issue. It is also a tool for management to receive reports on what user issues exist and the resources necessary to support users in a timely manner.

Capturing members through sticky products has started with the implementation of our new Instant Issue Debit Card solution.

Web site enhancements have begun with changes to the Symitar interface that allows our members to change their address behind our Cyberteller portal. Prior to this implementation, this was a manual and tedious process for both members and employees.

Social Media was enhanced through updating Facebook and Twitter on a regular basis. Information presented in this venue included financial tips and member testimonials.

As the importance of IT was increasingly being recognized by the USF-FCU, the CIO began to present her reports at the monthly Board of Directors meetings. The two-year rollout plan summary for 20112012 is included as Exhibit 7. Other opportunities identified included debit and credit card rewards, online account opening, relationship pricing, Symitar Budgeting Application, and Symitar Advanced Reporting for Credit Unions.

\section{Current Situation}

By early spring 2012, it was evident that the move to a more intensively technology supported credit union was ushering in opportunities for additional services and enhanced services. These opportunities were not always easy to exploit, however. Shelli Nicola, AVP of Human Resources, and Skaggs expressed some of the challenges associated with the implementation of technology at the credit union, particularly as it would impact both member and employees of USF-FCU. 


\section{WILL \& SKAGGS}

The changes for employees include a change in productivity expectations. Transactions will need to take place in a more consulting environment. Information relating to the interactions of members accounts is now available to credit union staff. Each credit union employee will be expected to identify opportunities available to members based on a variety of account information. For example, a member may have a large sum of money in a lower interest bearing account that could benefit from a move to a Money Market account or a Certificate of Deposit. Members may not be aware of special interest rates or other available opportunities.

Nicola voiced the need to provide training to all employees. Training could include programs to enhance interviewing skills, and the ability to identify cross-selling opportunities. Both Skaggs and Nicola indicated these issues have major implications beyond training, noting:

Incentive programs may need to change to reward staff, and associated performance measures may need to change.

The question was raised on how the "metrics" to evaluate employee performance would change. Hiring practices would have to be examined. The personnel need was moving from efficient transaction processing to problem solving and opportunity identification abilities.

It had been noted that Amazon.com attributes over 30\% of its sales to automated "cross-selling" of products. (e.g., Since you just put a camera in your shopping basket, you might be interested in a high capacity memory card or a carrying case specifically designed for it.) Both personal face-to-face and automated cross-selling were seen to be issues of increasing importance to USF-FCU.

Mr. Rick Skaggs and Ms. Shelli Nicola also expressed a need to determine appropriate initial and adaptive measures for addressing the current issues raised by a shifting technology environment. Training, incentives, rewards, evaluation were issues that would need to evolve as the implementation of technology related enhancements and services continued.

\section{Setting USF-FCU Priorities}

Although the annual Strategic Planning Session for 2012 had concluded a few weeks ago, it seemed like yesterday. Rick Skaggs had yet to catch his breath and now it seemed like even more "opportunities" popped up on the radar and some of the planned initiatives needed "timeline" adjustments. For example, President Skaggs indicated that a very recent change in priorities moved up a planned rollout of the Corporate Credit Card from July 2013 to "right now." He also indicated that the initiatives seem to need continuous prioritization. The major planned initiatives are detailed in Exhibit 8.

Skaggs has been looking forward to the challenges presented to and opportunities shaped for the USF Federal Credit Union. At least one of the staff members and a board member reminded Mr. Skaggs that a look back over the last couple of years would show significant progress towards the goals set forth in that strategic planning session just two years previously. Regardless, Skaggs had to keep his focus on the issues, challenges, and opportunities of the present and the future. He was still concerned about missing opportunities that could benefit the members of the credit union. He was also welcome to suggestions about the prioritization of the planned incentives. 


\section{Acknowledgements}

This case study is based upon work supported by the National Science Foundation under Grant No. 1043919.

\section{References}

Guinnane, T. W. (2001). Cooperatives as information machines: German rural credit cooperatives, 1883-1914. Journal of Economic History, 61(2), 366-389.

\section{Biographies}

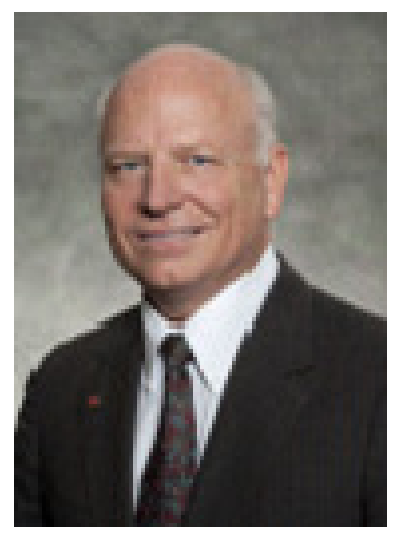

Richard Will is an Associate Professor in the Information Systems and Decision Sciences department at the University of South Florida. He holds a doctorate in Management Information Systems from The University of Houston, College of Business, where he also received his M.B.A. His B.S. was received from the College of Technology, also at the University of Houston. $\mathrm{He}$ is on the board of directors for the USF Federal Credit Union, and assists in multimedia applications projects for The Jimmy Carter National Historic Site, Education Program. His current research intrests include project management, systems development and multimedia applications.

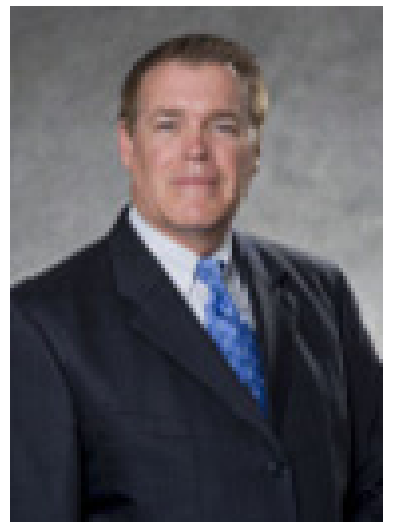

Rick Skaggs is the President and CEO of the USF Federal Credit Union. He was previously the top executive at Consumer Credit Counseling Service of Central Florida, headquartered in Orlando. Under his leadership, the USFFCU was awarded the Diamond Award from the CUNA Marketing and Business Development Council in the complete campaign category, won two awards at the $33^{\text {rd }}$ Annual Telly Awards competition for their piece titled "The Best Bull," and orchestrated the University of South Florida Alumni Association officially USF-branded VISA ${ }^{\circledR}$ credit card. 
WILL \& SKAGGS

\section{Exhibit 1: USF Federal Credit Union Mission Statement}

Our Credit Union is a financial institution owned and controlled by Members for their benefit that:

- Delivers superior service in a friendly and courteous manner with respect for the worth and dignity of all its members

- Promotes thrift and the cooperative ideals of the credit union philosophy

- Offers loans and deposit accounts at competitive rates and high quality financial services at fair prices for users of those services

- Maintains long-term financial stability to insure security of member deposits

- Is a responsible member of the University community 


\section{Exhibit 2: USF Federal Credit Union Key Indicators}
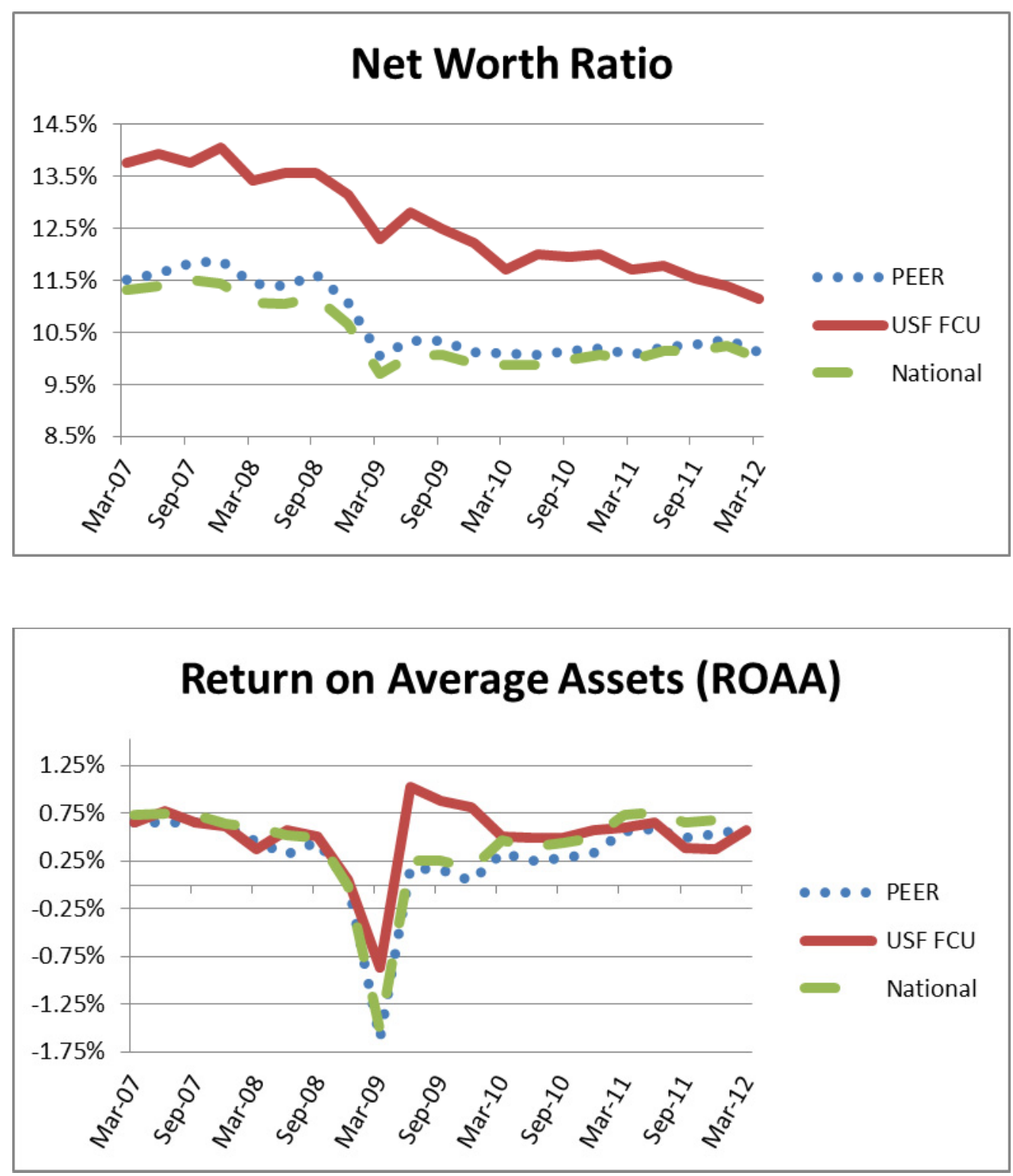
WILL \& SKAGGS
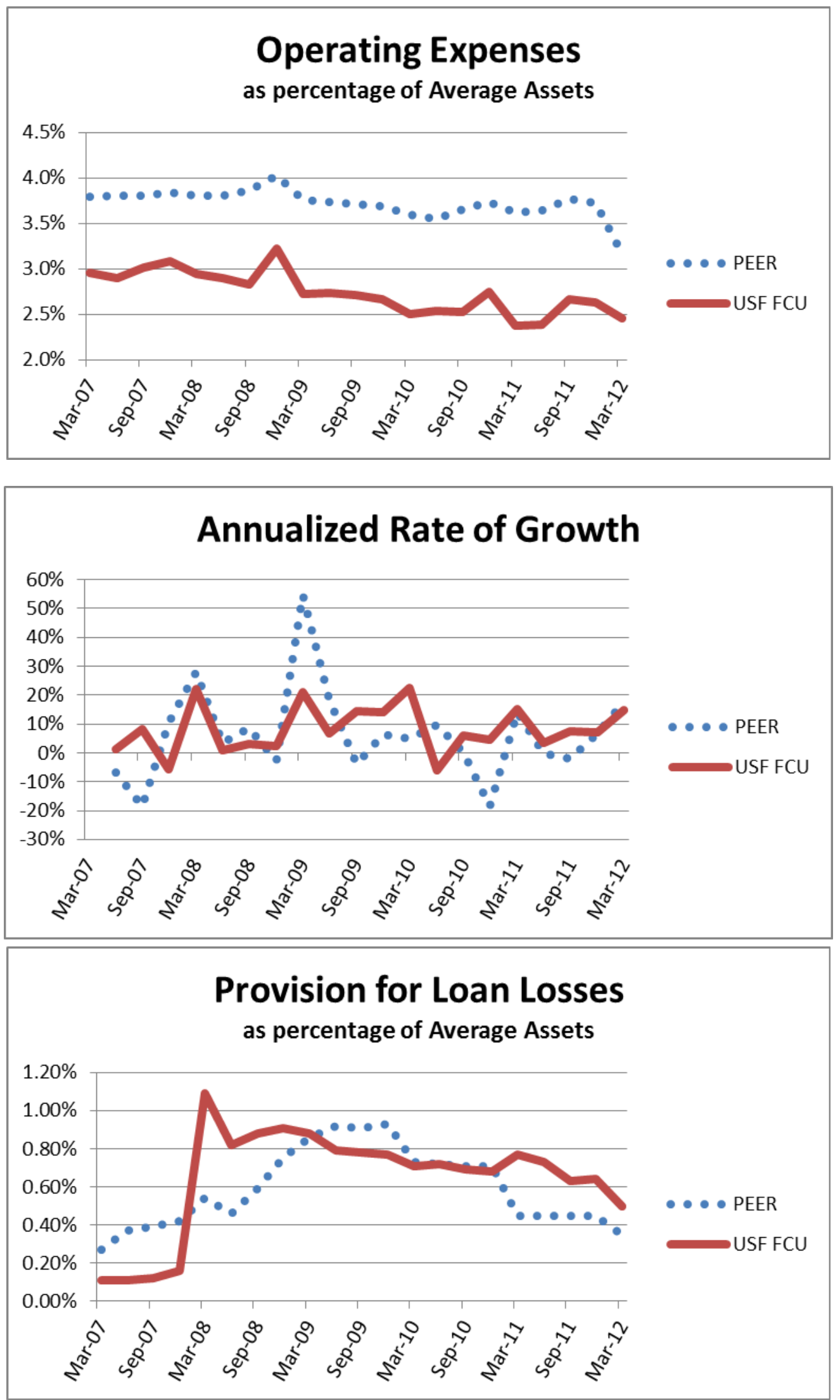


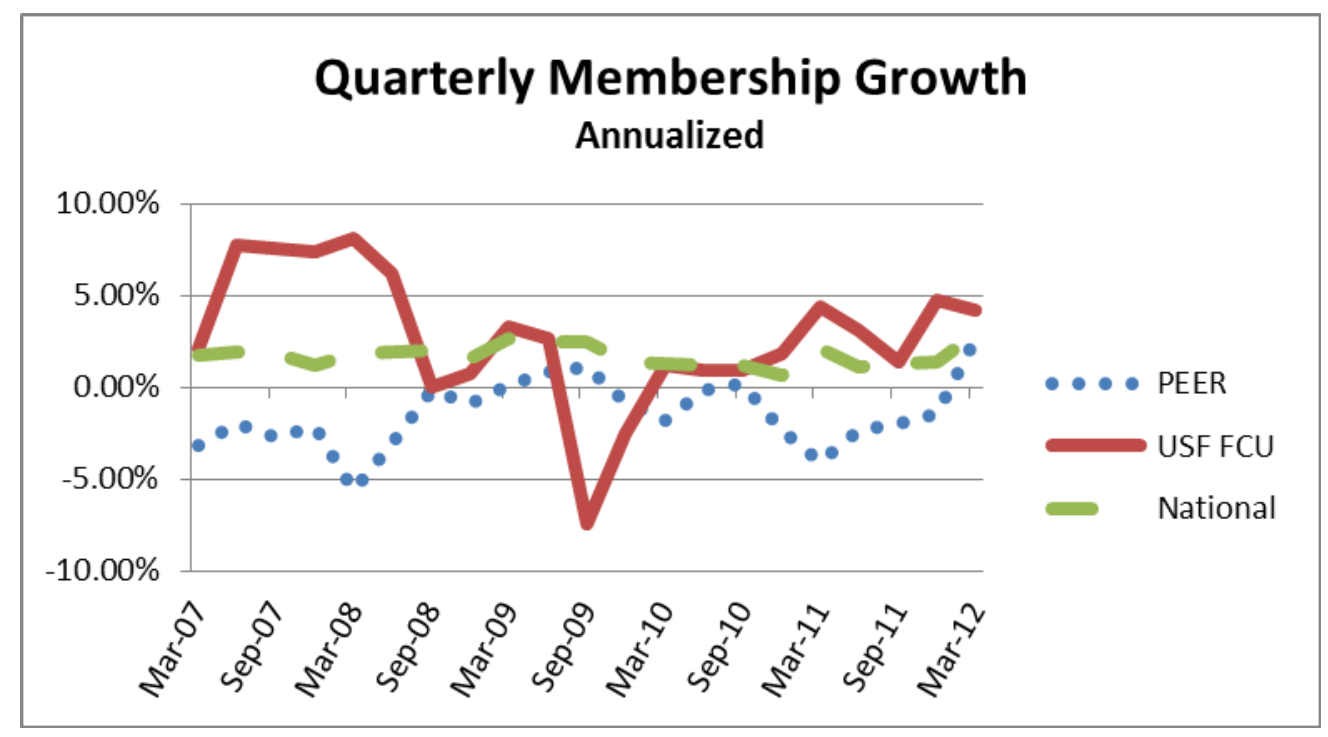




\section{Exhibit 3: USF Federal Credit Union Senior Management Team}

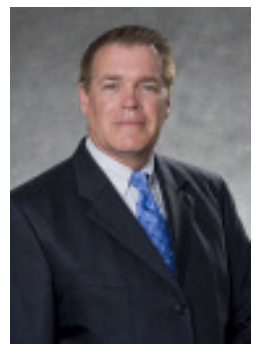

Richard Skaggs,

President/CEO

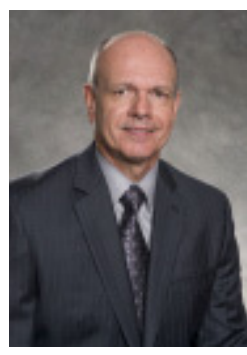

Bruce Koehler, Senior Vice President

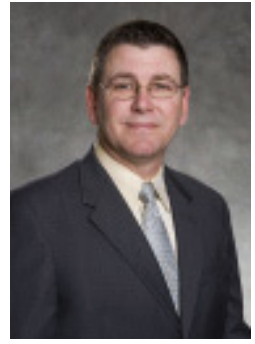

Miles Strickland, Chief Financial Officer

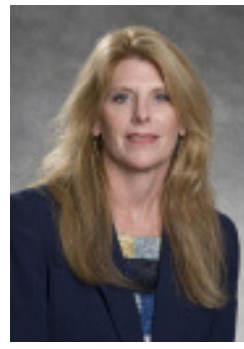

Peggy Yenny, Chief Information Officer

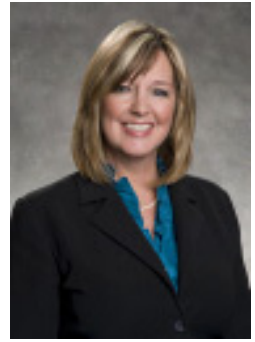

Shelli Nicola, Assistant Vice President of HR

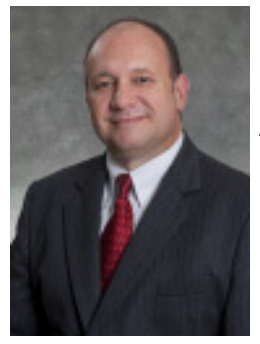

John LoCascio, Assistant Vice President of Retail Operations 


\section{Exhibit 4: USF Federal Credit Union Board of Directors}

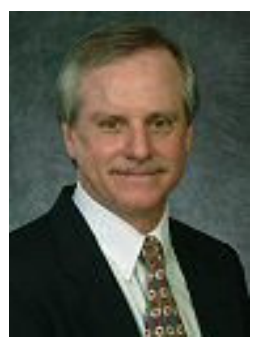

Dr. Scott Besley, Chair

Volunteer Since 2002

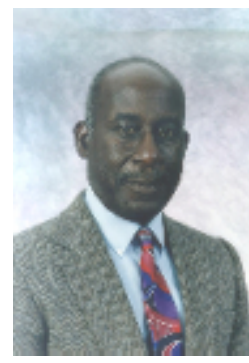

Willie Stokes,

Vice Chair

Volunteer Since 1996
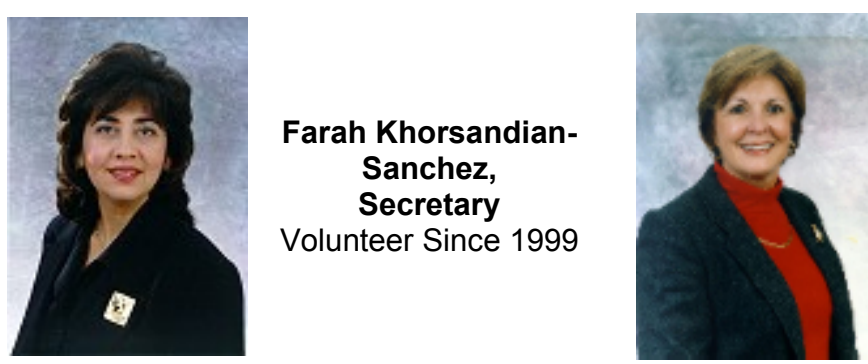

Farah Khorsandian-

Sanchez,

Secretary

Volunteer Since 1999
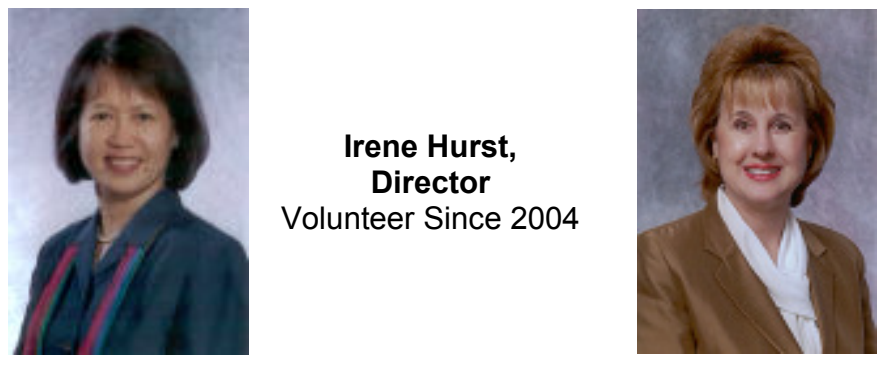

Liz Karl,

Treasurer

Volunteer Since 1998

Irene Hurst,

Director

Volunteer Since 2004

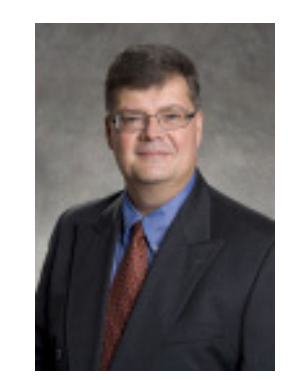

\section{Sandra Conway,}

Director

Volunteer Since 2006

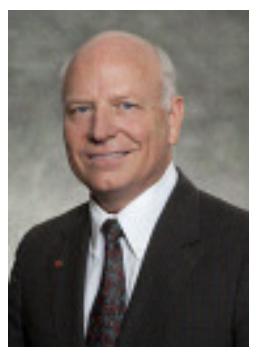

Dr. Rick Will, Director

Volunteer Since 2008

Dr. Ronald

Satterfield,Associate Director

Volunteer Since 2006 


\section{Exhibit 5: USF Federal Credit Union Supervisory Committee}

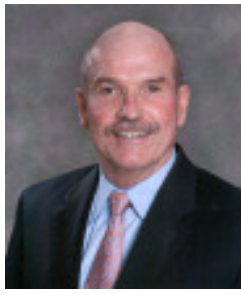

Eric Hunter,

Chair

Volunteer Since 2010

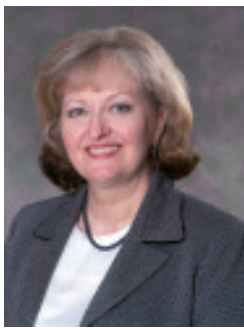

Roberta B. Friedlander

Volunteer Since 2010

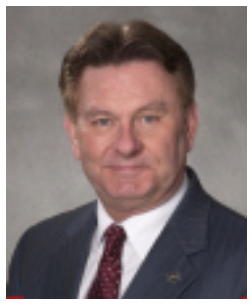

Dr. Dwayne Smith

Secretary,

Volunteer Since 2010

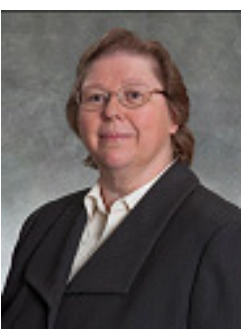

Dr. Robin Esring

Volunteer Since 2011 


\section{Exhibit 6: In-House and Outsourced Comparison}
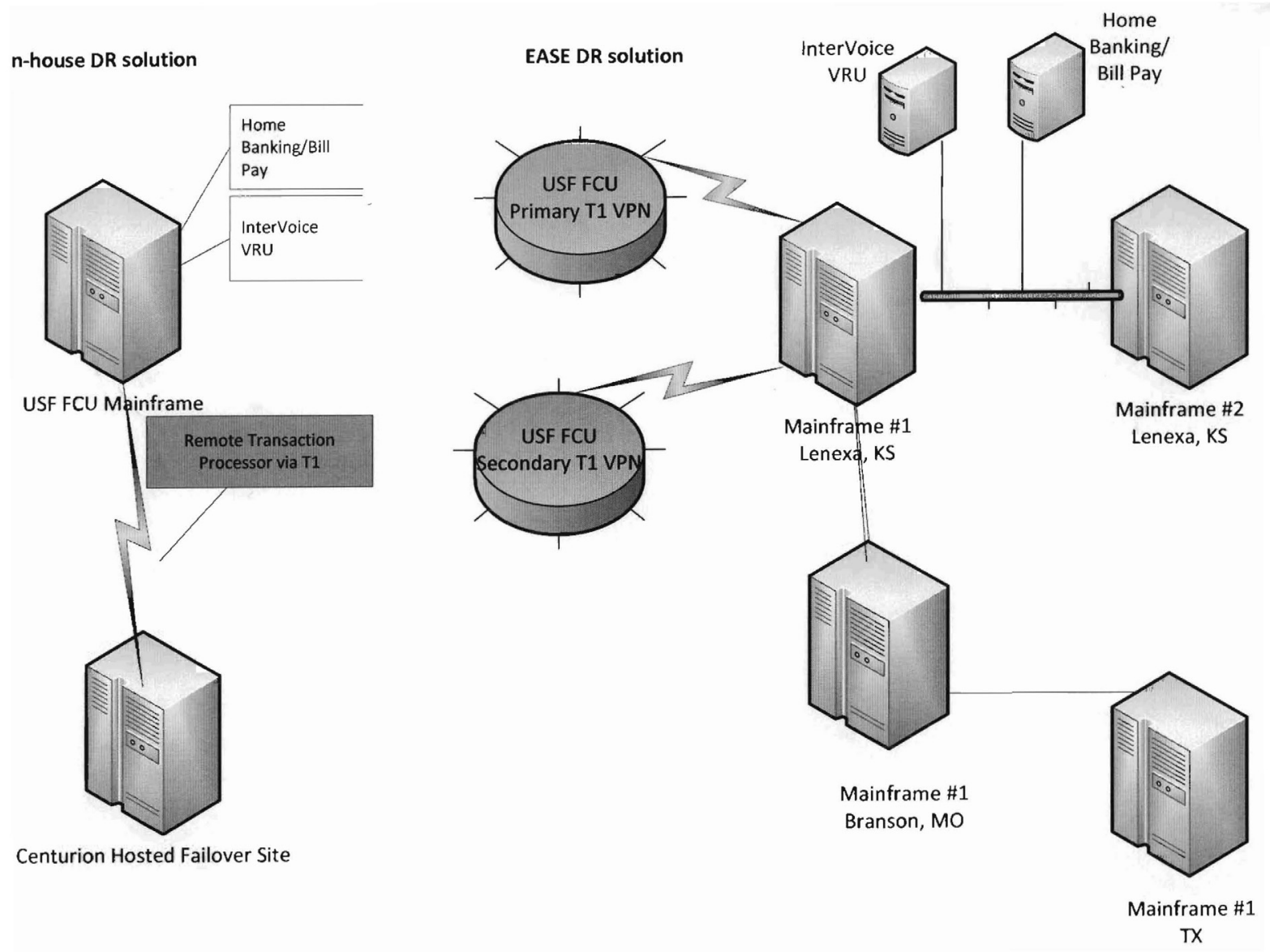


\section{Exhibit 7: USF-FCU Rollout Schedule}

\begin{tabular}{|c|c|}
\hline $11-1^{\text {st }} Q$ & - Facebook and Twitter accounts established \\
\hline $2011-2^{\text {nd }} Q$ & $\begin{array}{l}\text { - Assessment of core processing systems and network infrastruc- } \\
\text { ture to identify critical needs }\end{array}$ \\
\hline $2011-3^{\text {rd }} Q$ & $\begin{array}{l}\text { - } \text { IT Risk Assessment completed } \\
\text { - New signature pads for teller areas } \\
\text { - Disaster recovery procedures updated and distributed } \\
\text { - HVAC system for computer room upgraded } \\
\text { - ATM ADA compliance } \\
\text { - Workplace/desktop standardization } \\
\text { - Manual payroll process to desktop automation }\end{array}$ \\
\hline $2011-4^{\text {th }} \mathrm{Q}$ & $\begin{array}{l}\text { - Core processing migration from in-house to Service Bureau } \\
\text { EASE(Episys as a Service) platform } \\
\text { - Help Desk and Project Management solution implemented } \\
\text { - Rolled out new PCs and Windows } 7 \text { upgrade } \\
\text { - Intranet solution for documentation and reporting } \\
\text { - Instant Issue VISA Debit card solution implemented } \\
\text { - USF Health / Tampa General ATM installed } \\
\text { - Web Content Filtering to help control SPAM, virus protection, } \\
\text { Data Leak Prevention (DLP) and secure e-mail. }\end{array}$ \\
\hline $2012-1^{\text {st }} Q$ & $\begin{array}{l}\text { - Episys Quest upgrade - Symitar's new user interface } \\
\text { - CAMLS (Center for Advanced Medical Learning and Simulation) } \\
\text { ATM installation } \\
\text { - CyberCafe Cyberteller kiosk installed at Marshall Center } \\
\text { - Money-Line/Interactive Voice Response upgrades } \\
\text { - Redundant Internet backbone through USF network infrastruc- } \\
\text { ture }\end{array}$ \\
\hline $2012-2^{\text {nd }} Q$ & $\begin{array}{l}\text { - ATM security/firewall upgrades } \\
\text { - ATM install in USF Recreation } \\
\text { - Account Cross Sell (ACS) solution implementation to support di- } \\
\text { rect sales initiatives. [ACS supports the refinancing of loans and } \\
\text { credit cards that members have with competitive institutions by } \\
\text { automatically accessing individual credit reports and identifying } \\
\text { opportunities.] } \\
\text { - Home Banking Bill Pay } \\
\text { - Online Financial Manager (OFM) and Account Aggregation Solu- } \\
\text { tion which allows members to view account balances and trans- }\end{array}$ \\
\hline
\end{tabular}


actions, analyze spending and net worth, and create and manage budgets.

- Server Virtualization

$2012-3^{\text {rd }} Q$

- E-notices

- E-tax forms

- Mobile banking to give members the ability to perform routine banking transactions using a cell phone, PDA, or other mobile device.

- USF Alumni Association Affinity Program (credit/debit cards)

- Symitar Release 2012 testing

$2012-4^{\text {th }} \mathrm{Q} \quad$ - Web-site redesign

- Enhanced Member Application (EMA) implementation that automates the account opening process. 


\section{Exhibit 8: USF Federal Credit Union Major Initiatives}

\begin{tabular}{|c|c|c|}
\hline & $\begin{array}{c}\text { Initiatives / Possible } \\
\text { Initiatives }\end{array}$ & Overview \\
\hline 1 & Opening Act-Affinity & $\begin{array}{l}\text { Vendor- SYMITAR } \\
\text { Member Application, Account Opening, and Consumer Loan } \\
\text { Web-based solution. } \\
\text { Opening Act offers potential members easy access to credit union } \\
\text { membership, and gives current members the freedom to open and } \\
\text { fund new accounts and apply for loans online. This system will } \\
\text { perform ID Verification, OFAC check, ChexSystems, Credit Re- } \\
\text { port, and fund the account. Additionally, it includes a Switch Kit } \\
\text { and a powerful Cross-Selling system with the capability for online } \\
\text { loan approval. } \\
\text { The system also allows potential members to open an account } \\
\text { online without coming to a branch. Students and families will be } \\
\text { able to open membership from anywhere there is internet capabil- } \\
\text { ity. }\end{array}$ \\
\hline 2 & $\begin{array}{l}\text { Enhanced Member Applica- } \\
\text { tion } \\
\text { (EMA) }\end{array}$ & $\begin{array}{l}\text { Vendor- SYMITAR } \\
\text { Automates the new member application process allowing staff to } \\
\text { be more efficient and focus on member service. This process } \\
\text { improvement will significantly reduce the amount of time it takes } \\
\text { to open an account, reduce errors, and minimize training time. } \\
\text { This system takes us from a manual process to an automated } \\
\text { workflow process. Member Service representatives will be able to } \\
\text { open accounts much quicker and help the next member sooner } \\
\text { which will reduce wait times. }\end{array}$ \\
\hline 3 & Imaging & $\begin{array}{l}\text { Enterprise Content Management/Imaging: } \\
\text { An ECM does more than simply archiving, it encompasses } \\
\text { strategies and tools to capture, manage, store, preserve and } \\
\text { deliver member documents. It provides a work flow for the life } \\
\text { cycle of documents, from initial scanning to end of life } \\
\text { destruction. }\end{array}$ \\
\hline
\end{tabular}




\begin{tabular}{|c|c|c|}
\hline 4 & Mobile Banking & $\begin{array}{l}\text { Access personal or business accounts by utilizing a cell phone or } \\
\text { web-enabled smartphone. This FREE, SECURE and easy to use } \\
\text { service puts financial management in the palm of your hand. } \\
\text { Mobile Apps } \\
\text { Use your smartphone (iPhone/Android device) to check account } \\
\text { balances, view transaction histories, transfer funds, make pay- } \\
\text { ments, find nearest branch locations, pay bills, and view alerts. } \\
\text { Mobile Web } \\
\text { Use any mobile device with web capabilities to instantly access } \\
\text { account balances, see detailed transaction histories, make loan } \\
\text { payments, transfer money between your accounts or even locate } \\
\text { the nearest USF FCU branch. } \\
\text { Mobile Text } \\
\text { Use your phone's text messaging feature to check account bal- } \\
\text { ances or view transaction history. }\end{array}$ \\
\hline 5 & Fl to Fl & $\begin{array}{l}\text { Vendor- SYMITAR } \\
\text { FI Transfer allows HomeBanking users to transfer funds between } \\
\text { accounts held at the Credit Union and accounts held at another } \\
\text { financial institution. FI transfer is also known as FI-to- FI } \\
\text { Transfer, Interbank Transfers (IBT) or Bank-toBank transfers } \\
\text { (B2B). }\end{array}$ \\
\hline 6 & Network Redesign & $\begin{array}{l}\text { Network Topology Re-design and Virtualization: } \\
\text { Our initiative is to replace our network platform by consolidating } \\
\text { the dated servers and to implement a Virtualized Server } \\
\text { environment and backup solution. This solution will provide } \\
\text { faster data access for employees and less administration time for } \\
\text { IT staff. More importantly it will provide a fully redundant server } \\
\text { failover and backup storage solution. }\end{array}$ \\
\hline 7 & Phone System Upgrade & $\begin{array}{l}\text { Implement a state-of-the-art telephone solution that will provide } \\
\text { the capability to have member calls routed to the staff experts via } \\
\text { skill based routing technology. Once the members' call is routed, } \\
\text { their account information will automatically populate on the staff } \\
\text { member's computer. }\end{array}$ \\
\hline
\end{tabular}




\begin{tabular}{|c|c|c|}
\hline 8 & $\begin{array}{l}\text { Account/Service } \\
\text { ability Analysis }\end{array}$ & $\begin{array}{l}\text { The account and product profitability project involves the review } \\
\text { and selection of a vendor/partner offering a system capable of } \\
\text { identifying, mapping, allocating and reporting direct and indirect } \\
\text { costs and revenues to the credit union's member accounts and } \\
\text { products offered. The outcome of the project is the successful } \\
\text { implementation of a system that will help management to } \\
\text { determine the appropriate pricing of its financial products and } \\
\text { services, as well as to determine what types of relationships are } \\
\text { most advantageous to the credit union. } \\
\text { This knowledge is necessary to construct an effective relationship } \\
\text { pricing model. In addition, a good system would be able to } \\
\text { identify the profitability of individual accounts. A good system } \\
\text { will also be able to identify specific relationships from a } \\
\text { profitability standpoint so the credit union will be able to focus } \\
\text { attention on our most valuable members. Finally, the system } \\
\text { should also provide assistance in identifying mass-marketing } \\
\text { candidates through the analysis of member relationships and } \\
\text { demographics. }\end{array}$ \\
\hline 9 & Sales and Service Tracking & $\begin{array}{l}\text { Software solution that provides an easy way to plan, distribute } \\
\text { and monitor incentive plans by tracking cross-selling results. } \\
\text { Includes Sales \& Service Management, Referral Management, } \\
\text { Incentive Management, Promotion Management, Activity } \\
\text { Management, and Performance Management. }\end{array}$ \\
\hline 10 & Website Redesign & $\begin{array}{l}\text { Develop efficient functionality, smart architecture, and easy } \\
\text { navigation. Waiting for new VP of Marketing to provide design } \\
\text { options. }\end{array}$ \\
\hline 11 & Wire Transfer System & $\begin{array}{l}\text { Wire Transfer Module is a workflow solution that supports } \\
\text { incoming wires as well as outgoing wires, ensuring the wires are } \\
\text { posted to the correct accounts. All wire transactions go through } \\
\text { necessary approval steps. }\end{array}$ \\
\hline 12 & Self-Service Member System & $\begin{array}{l}\text { Allows member to sign-in without waiting for staff assistance. } \\
\text { This would allow for the front desk employee to provide member } \\
\text { service rather than signing-in members. This would provide faster } \\
\text { service and increased productivity. }\end{array}$ \\
\hline 13 & $\begin{array}{l}\text { Corporate Credit Card Pro- } \\
\text { gram }\end{array}$ & $\begin{array}{l}\text { Vendor - SYMITAR AND PSCU } \\
\text { The product will be targeted to member small businesses and } \\
\text { business units housed on the campuses of the University of South } \\
\text { Florida. It will act as a complement to our USF Alumni } \\
\text { Association affinity card product and positions the credit union to } \\
\text { expand our relationships on campus. }\end{array}$ \\
\hline
\end{tabular}

